\title{
Port Authority's Corporate Social Responsibility (CSR) and Perceptions of Entrepreneurs and Port Enterprises ${ }^{*}$
}

José Boza ${ }^{\star \star}$, Matías M. González ${ }^{\star \star \star}$, Javier de León***

* Artículo de investigación

** Ph.D. in Economics from University of Las Palmas de Gran Canaria, University Institute of Tourism and Sustainable Economic Development, University of Las Palmas de Gran Canaria, Spain. E-mail: jchirino@ulpgc.es

*** Ph.D. in Economics from University of Las Palmas de Gran Canaria, University Institute of Tourism and Sustainable Economic Development, University of Las Palmas de Gran Canaria, Spain. E-mail: matiasmanuel.gonzalez@ulpgc.es

$* * * *$ Ph.D. in Economics from University of Las Palmas de Gran Canaria, University Institute of Tourism and Sustainable Economic Development, University of Las Palmas de Gran Canaria, Spain. E-mail: javier.leon@ulpgc.es

Recibido: 20 de agosto del 2016 Aprobado: 22 de enero del 2017

Cómo citar este artículo: Boza, J., González, M. M. y de León, J. (2017). Port authority's Corporate Social Responsibility (csr) and perceptions of entrepreneurs and port enterprises. Cooperativismo \& Desarrollo, 111(25), 53-66. doi: https://doi.org/10.16925/co.v25i111.1771

\begin{abstract}
Introduction: The Spanish Ports Act of 2010 (33/2010) is one of the ground-breaking laws that obliges Port Authorities, which are public institutions, to pursue sustainable development, justify the actions undertaken and disclose their results in annual Sustainability Reports. Methodology: Structural Equation Models (SEM) were used with an unobserved dependent variable: "the values or transmission of the port authority's values" and two latent explanatory variables: "Relational climate with port authorities" and "Environmental conditions in the port"; the parameters have been estimated by the maximum likelihood procedure. Results: The results of the Structural Equation Model (SEM) applied in this study confirm the existence of a direct and positive relationship between the climate of relations and the port authority's ethical values, and an additional direct effect of the environmental value on the endogenous variable, which produces an unexpected negative value. Conclusions: The results show that the Social Responsibility report is a necessary tool to explain how the Port Authorities carry out Social Responsibility actions, but it is also perceived that they are of little practical use, as they are too technical and non-binding for the stakeholders.
\end{abstract}

Keywords: Corporate Social Responsibility (CSR), port authority, stakeholders' perceptions, Structural Equation Models (SEM). 


\title{
Responsabilidad Social Empresarial de la Autoridad Portuaria y Percepciones de Empresarios y Empresas Portuarias
}

\section{Resumen}

Introducción: La Ley de Puertos española de 2010 (Ley 33/2010 de agosto 5) es una de las leyes innovadoras que obligan a las autoridades portuarias, que son instituciones públicas, a buscar el desarrollo sostenible, justificar las acciones emprendidas y divulgar sus resultados en informes anuales de sostenibilidad. Metodología: Se emplearon modelos de ecuaciones estructurales (SEM) con una variable dependiente no observada: "los valores o transmisión de los valores de la autoridad portuaria" y dos variables explicativas latentes: "clima relacional con autoridades portuarias" y "condiciones ambientales en el puerto"; los parámetros se estimaron mediante el procedimiento de máxima verosimilitud. Resultados: Los resultados del modelo de ecuación estructural (SEM) aplicado en el presente estudio confirman la existencia de una relación directa y positiva entre el clima de las relaciones y los valores éticos de la autoridad portuaria, y un efecto directo adicional del valor ambiental sobre la variable endógena, lo cual produce un valor negativo inesperado. Conclusiones: Los resultados muestran que el informe de responsabilidad social es una herramienta necesaria para explicar cómo realizan acciones de responsabilidad social las autoridades portuarias, pero también se identifica que resultan tener poca utilidad práctica, ya que son demasiado técnicos y no vinculantes para los interesados.

Palabras clave: responsabilidad social empresarial (RSE), autoridad portuaria, percepciones de las partes interesadas, modelos de ecuación estructurales (SEM).

\section{Responsabilidade Social Empresarial (RSE) da autoridade portuária e percepções de empresários e empresas portuárias}

\begin{abstract}
Resumo
Introdução: a Lei de Portos espanhola de 2010 (Lei 33 de 5 de agosto de 2010) é uma das leis inovadoras que obrigam as autoridades portuárias, que são instituições públicas, a buscar o desenvolvimento sustentável, justificar as ações empreendidas e divulgar seus resultados em relatórios anuais de sustentabilidade. Metodologia: foram utilizados modelos de equações estruturais (SEM) com uma variável dependente não observada: "os valores ou a transmissão dos valores da autoridade portuária" e duas variáveis explicativas latentes: "clima relacional com autoridades portuárias" e "condições ambientais no porto"; os parâmetros foram estimados mediante o procedimento de máxima verossimilhança. Resultados: os resultados do SEM aplicado neste estudo confirmam a existência de uma relação direta e positiva entre o clima das relações e os valores éticos da autoridade portuária, e um efeito direto adicional do valor ambiental sobre a variável endógena, o que produz um valor negativo inesperado. Conclusões: os resultados mostram que o relatório de responsabilidade social é uma ferramenta necessária para explicar como as autoridades portuárias realizam ações de responsabilidade social, mas também se identifica que resultam ter pouca utilidade prática, já que são muito técnicos e não chamativos para os interessados.
\end{abstract}

Palavras-chave: autoridade portuária, modelos de equação estruturais (SEM), percepções das partes interessadas, responsabilidade social empresarial (RSE). 


\section{Introduction}

The Spanish Ports Act of 2010 (33/2010) concerning Spanish port and maritime policy includes sustainability and Corporate Social Responsibility (CSR) in the port authority management model. This is an aspect which is considered fundamental by the Department of State Ports for ports to add to competitiveness within the Spanish productivity system (Spanish ports are responsible for $85 \%$ of all imports and $50 \%$ of exports). Moreover, due to their strategic situation-in midstream of the major shipping routes, the so-called motorways of the sea-, seaports in Spain have been boosted enormously since the outset of the European Union. The Ports Act of 2010 $(33 / 2010)$ requires that port authorities compile and disclose the results and conclusions of all annual RsC sustainability reports. It is a concept conceived by the United Nations World Commission on Environment and Development, which took the $3^{\text {rd }}$ Principle of the Rio Declaration (1992) as a point of reference for sustainable development: "The right to development must be fulfilled so as to equitably meet developmental and environmental needs of present and future generations." On this basis, the concept of sustainability has evolved, and current efforts in favour of sustainable development are centred on three fronts: environmental, economic and social. As from 2011, all Spanish Port Authorities have respectively disclosed sustainability reports, each using the same benchmarks regarding their achievements and dividing them into four different areas: institutional, economic, environmental and social. The only aim of classifying the information in the reports is to improve organisation for a clearer layout and presentation.

The main criticism regarding the misuse of sustainability reports arises when they are used for marketing purposes. Leipziger (2003), on referring to sustainability reports, explains that these rules or guidelines provide great advantages in the sense that they lay out a directory of practice and procedures regarding responsibility, which can be of great use to create and implement responsible managerial strategies, to manage activity within society itself, or to achieve change in specific procedures. If the guidelines are taken for granted by firms or interested third parties who are liable to profit from them, negative consequences may arise such as companies acquiring the "Systematic Filling Out of Forms" syndrome (in other words, simply complying with what has already been perceived).
Boza (2011) carried out his research in 1,363 companies that had gained recognition from the GRI ${ }^{1}$ in 2009, the majority being evaluated with the highest standards (A, A+). Amongst some with the most favourable standards was the RSC Annual Report on Finance Services, above all, the Annual Reports published by the Confederation of Savings Banks in Spain (Cajas de Ahorros - 75\%), the excellent standards these financial firms obtained did not reflect the reality in any way. These enterprises, in fact, had fallen into bankruptcy and needed public funding to bail out-not a very good example of sustainability and CRS on the part of the Cajas de Ahorros, these having misspent resources on CRS and therefore losing trust and a good reputation as far as stakeholders were concerned-. A full picture of whether a firm is socially responsible or not cannot be obtained by only taking an annual report into consideration; they are very useful as far as guidelines go, and well worth when starting up in business, but in practice none are able to certify or merely verify if a firm or organization follows a procedure which is considered responsible or sustainable.

Regulating the CSR is not very common, and is onlyconsidered voluntaryinfavour of society; however, there are certain aspects of the CRS which do come under legislation, these having plausible explications. Steurer (2010) studies the leading role being played by governments together with the traits of European public policies concerning CRS. According to this author, CRS is not simply a novelty encompassed by global strategy aimed at sustainability. In his research, he explains that governments introduce CRs basically for three reasons. Firstly, because governments engage in general objectives such as human rights, aiding development, anti-racial and sex discrimination, etc. Secondly, CRS is considered parallel to legal regulation which is politically undesirable for a number of stakeholders and interested third parties -hard law-, whereby the concept of "responsibility" adds

1. The G-3 guidelines set out in the GRI are the most widely used internationally and have served as a basis for more recent guidelines. The G-3 guidelines put companies into three categories: C, B and A. The fixing of standards is merely discretionary and is based on the number of Performance Indicators included in the report. As the number of these indicators rises, firms will be classified with a higher standard. The plus standards (,$+ \mathrm{B}+$ and $\mathrm{A}+$ ) can only be achieved through external recognition in the report -external assessment-. Nevertheless, the G-3 guidelines themselves point out that standards are not certifications, but mere verifications. 
a positive effect, overseeing stakeholders by means of very light-handed legislation — soft law-. Thirdly, material contributions are based on a voluntary basis, a setting in which legislation is no longer applicable. In the words of the author, CRs on global terms shows signs of being a close approximation to a new way of governing.

The objective of this study is to specify a model which can be used to explain the causes that influence stakeholders' perceptions concerning the Port Authority's ethical behaviour and analyse the consequences. If these consequences are of any importance and, at the same time beneficial, the coming into force of the Ports Law and the actions and measures being taken by the port authorities will all have a positive effect on the stakeholders' perceptions. On the contrary, if the effects are negative, this very model will recommend what type of measures will be able to improve these very perceptions.

Thisresearchisdividedintofoursections. Following the Introduction, Section 2 consists of a review of the literature, selected in line with the empirical research work which concentrates on the study of stakeholders' perceptions. In section 3 , an explication of the variables is given, together with different hypotheses, the specifications of the model and the methods of estimation used. In Section 4, the results of the causal estimations, the significance of the statistics and the goodness of fit are observed and deliberated on. Ultimately, in Section 5 , an explanation of the conclusions is presented.

\section{Background}

The research projects carried out by Carroll (1991) and Wood (1991) are considered pioneering in the conceptualization of CSR. Carroll (1991), based on the alternative definitions that rapidly spread throughout the 1960s, '70s and '80s, defines different stages and levels of Social Responsibility. It is represented by means of a pyramid whose base represents Economic Responsibility - firms must be profitable-, while on the second level lies Legal Responsibility - firms must act within a legal framework-. On the third level comes Ethical Responsibility - good practice must be encouraged-, and finally philanthropy sits at the top - voluntary initiatives with a view to promoting the welfare of others in society-. On the other hand, the research carried out by Wood (1991) defines the concept of Corporate Social Performance (CSP), which became the basis for the Stakeholder theory together with the Ethical Business theory.
In spite of the wide span of perspectives that appear within the corresponding literature, the research carried out by Aguinis and Glavas (2012) adds a certain degree of order; by reviewing the literature on sustainability and CSR, the authors could classify 558 articles and 102 books and book chapters into three main groups: institutional, organizational or individual. The group referring to the institutional section includes research on CSR related to aspects of rules, culture and regulation which have a bearing on CSR - economic conditions, legislation, the economy, and influence on stakeholders, etc-. The second level, concerning organizational issues, underlines the most significant research work related to business motivation, product quality, and investors, amongst others. Lastly, at individual level, the most prominent factors within CSR are people themselves, as they are precisely the source of decision-making concerning CSR and those responsible for putting it into practice. From a more operating point of view, in the last years, guides have been developed to apply the cSR to both companies and governments. Related to social responsibility, we highlight the GRI (Global Reporting Initiative) Guide and the Iso 26000 standard as well as the Iso 14000 standard, which refers to environmental management in the activities of companies. Some of the most important aspects that are explicitly stated in the Iso 26000 standard are its voluntary use, the different degree of commitment among different countries, and above all, that it is only a procedure to enforce the CSR correctly. Iso 26000 standard would never be used to certify an organization as socially responsible.

The empirical research work on CSR and sustainability included in this review was selected because they met the three general selection criteria, that is, they use questionnaires, synthesize the information from the original variables in dimensions, and aim to explain stakeholders' perceptions by way of models. Along this line of thought the research carried out by the following is outstanding: Caro, García-Gordillo, Rodríguez, \& Jiménez (2007); Hamman, Habisch \& Pechlaner (2009); Chieh-Peng, Nyan-Myau, Yuan-Hui, Wen-Yung, \& Chou-Kang (2010); Eun Mi, Seong-Yeon \& Hyun Jung (2013); and Yongrok \& Yanni (2014).

Caro et al. (2007) look to measure up to what point managements are willing to put CSR into practice, by means of a number of independent variables rated on a Likert scale. The results of the estimations show signs of a slight cultural change concerning the stakeholders' perceptions, although no observations 
are mentioned as to what action should be taken with a view to making way for progress.

Alvarado and Schlesinger (2008) claim that corporate social responsibility programs and measures could improve a company's image and reputation; they researched the stakeholders' perceptions by using a model of structural relationships, in which they used a sample of 385 customers. The results indicate that there is a direct impact on the image which a brand name may have and indirect consequences on its reputation.

Chieh-Peng et al. (2010) see CSR as a kind of corporate autoregulation integrated in the business model, whereby the focus on CSR is centred on the perceptions of stakeholder groups in three fundamental aspects. Firstly, social responsibility is multidimensional due to its own nature (economic, legal, ethical and discretional), and secondly, it is highly important to know how to identify those who make up the stakeholders or interested third parties and what is expected from the organization. Thirdly, occasionally CSR may have negative effects on organizations, for example, at times expenses and efforts are made, but do not yield good results. These authors carried out an empirical study based on 421 personal questionnaires aimed at different business groups in Taiwan. Amongst the results obtained, one stood out amongst the rest: the stakeholder groups perceived the positive influence of the legal and ethical dimensions over those of CSR. However, the perception of discretional dimensions turned out to be negative; the authors go on to explain that this negative result may be due to situations where organizations take adverse discretional measures, which in turn, may prove to be unfavourable for the stakeholders.

In the model by Eun Mi et al. (2013), they develop and contrast employee perception in CSR. They associate perception with the degree to which a company supports activities aimed at social causes. Employee perception is considered as a variable with three dimensions: environmental, philanthropic and CSR ethical activities. The perceptions in CSR are construed as the adaptation among culture, CSR activity and the capacity to perceive CSR itself. The adaptation factor conveys the idea of transfer of knowledge or synergy of activities. Adaptation arises when company employees believe that CSR measures are congruent with the culture pertaining to an organization. The results suggest that CSR capacity together with the adaptation of the perceived culture help to increase productivity and the perception of
CSR; this being the reason why firms and businesses should consider that, in the long run, the advantages of employee perception of CSR boost cooperation and improve productivity.

Vinerean, Cetină, Dumitrescu, \& Țichindelean (2013) explain that for companies to be able to move towards progress and development, they must comply with all the requisites of sustainability and face up to challenges such as innovation, productivity, social equality and responsibility, together with environmental issues. With a sample consisting of 52 companies, they synthesize the information based on a set of variables in order to compare the relationships between CSR and employee satisfaction and levels of their commitment to the organization. The results from the estimations show that CSR and a healthy work climate can only yield advantages for the organization.

Chernyak-Hai and Tziner (2014) carry out research on judicial organization, the ethical environment and employee perception. The perception of the organizational environment is defined as tendencies which are the most important in the working environment such as policies, practices and procedures. The organizational environment forms part of a psychological process which helps employees to realize that they play an active role in the company. Yongrok \& Yanni (2014) also focus their work on the perceptions in and around the working environment, besides good work practices with employees.

Research into CSR by way of questionnaires and stakeholders' perceptions do not overlook small and medium enterprises (sMEs). Hamman et al. (2009) obtained results using questionnaires in small German firms, which confirm the idea that employees, customers and society itself are the most important interested parties for any of these companies; moreover, the survey found that the role of employees is fundamentally important for transmitting ethical values. Herrera et al. (2013) carried out a detailed review of research work on CSR related to SMES and stated that the role of the management, with their values and ethical beliefs, play a vital part at the time of deciding on one strategic choice of sustainable conduct or another. Fassin et al. (2014) undertook a study of six European countries (Belgium, Italy, Norway, France, the UK and Spain), the so-called mental model for small and medium enterprise management in relation to CSR. According to this author, CSR in these companies is interesting for one reason or another because, in general terms, the owner of a small business coincides 
with the role of manager and so he could organise CSR according to his personal values.

In synthesis, the research articles that have been reviewed here suggest that CSR has a multidimensional definition and coincide in measuring CSR by studying stakeholders' perceptions. They also concur in that organisations, enterprises and institutions should implement sustainable practices which, at the same time, should be socially responsible - these factors favouring relations and their environments- since they are being put under more and more pressure from all sides - employees, customers, investors, society, public administration, amongst others-. Finally, the slight differences among the research projects referred to above lie in the approaches concerning CSR. Some authors underline the social causes, such as Eun Mi Lee et al. (2013), while Johnson and Scholes (1999) give more relevance to the transference of ethical values; Chieh-Peng et al. (2010) emphasize corporate autoregulation; Vinerean et al. (2013) highlight progress and development; and lastly, Fassin et al. (2014) stress the management mental model.

\section{Variables and Model Specification}

The proposed model specification is based on a number of hypotheses which revoke the possible existence of any coincidental causal relations between stakeholders' perceptions and CSR activity implemented by port authorities after the Ports Act of 2010 (33/2010) became effective.

The variables included in this model, which focus on studying the causal relations, are latent, and their corresponding definitions and elements they contain, not only depend on what the research has for as an objective, but also the type of stakeholder the questionnaire is aimed at. Hongwei and Yan (2011), with the aim of studying the possible effects of CSR and consumer fidelity, resort to variables such as service quality and brand recognition each of which are variables that are not measured directly. Yongrok \& Yu (2014) measure the organizational performance by means of observing CSR activity, civic behaviour and organizational compromise, all of which are latent. The research work which connects the latent variables is set out by means of Structural Equation Models (SEM), which evaluate both the direct and indirect effects produced by the causes or unobserved explanatory variables.

For the purpose of measuring the model's dependent or latent variable ( $\eta$ ), the values or transmission of the port authority's values, two observable variables or measured variables, $\mathrm{Y}_{1}$ and $\mathrm{Y}_{2}$, are used (Table 1).
Table 1

Dependent Variable

\begin{tabular}{ll}
\hline & \multicolumn{1}{c}{ Measured variables } \\
\cline { 2 - 2 }$\eta$ : Values and & $\begin{array}{l}\mathrm{Y}_{1}: \text { Involvement of port authority in } \\
\text { social affairs. }\end{array}$ \\
\cline { 2 - 2 } $\begin{array}{l}\text { transmission of port } \\
\text { authority's values }\end{array}$ & $\begin{array}{l}\mathrm{Y}_{2}: \text { The port authority ensures that stake- } \\
\text { holders play an active role regarding its } \\
\text { values. }\end{array}$ \\
\hline
\end{tabular}

Source: Compiled by the authors.

Both latent independent variables, $\xi_{1}$ y $\xi_{2}$, are measured by means of observable explanatory variables $\mathrm{X}_{1} \ldots \mathrm{X}_{7}$ The first one, the perception of organizational environment adopts Yongrok \& Yu's definition (2014) by explaining the term climate as the predominating spirit in the relations with stakeholders regarding politics, practices and procedures. The second explanatory variable, environmental conditions, is measured by means of a number of variables, all related to pollution (Table 2).

Table 2

Latent Independent Variables

\begin{tabular}{|c|c|}
\hline & Measured variables \\
\hline \multirow{4}{*}{$\begin{array}{l}\xi_{1}: \text { Relational climate } \\
\text { with port authorities. }\end{array}$} & $\begin{array}{l}\mathrm{X}_{1} \text { : the company feels } \\
\text { integrated within the port. }\end{array}$ \\
\hline & $\begin{array}{l}\mathrm{X}_{2} \text { : the port authority } \\
\text { looks for ways to improve } \\
\text { relations with the } \\
\text { stakeholders. }\end{array}$ \\
\hline & $\begin{array}{l}\mathrm{X}_{3} \text { : services provided by the } \\
\text { port authority give clear, } \\
\text { transparent information. }\end{array}$ \\
\hline & $\begin{array}{l}\mathrm{X}_{4} \text { : the port authority } \\
\text { takes the suggestions } \\
\text { made by consumers and } \\
\text { entrepreneurs from the port } \\
\text { area into account. }\end{array}$ \\
\hline \multirow{3}{*}{$\begin{array}{l}\xi_{2}: \text { Environmental conditions } \\
\text { in the port. }\end{array}$} & $\begin{array}{l}\mathrm{X}_{5} \text { : the port authority } \\
\text { considers atmospheric } \\
\text { conditions sufficiently } \\
\text { relevant. }\end{array}$ \\
\hline & $\begin{array}{l}\mathrm{X}_{6}: \text { the port authority } \\
\text { considers land pollution } \\
\text { sufficiently important. }\end{array}$ \\
\hline & $\begin{array}{l}\mathrm{X}_{7} \text { : the port authority } \\
\text { considers noise pollution } \\
\text { sufficiently important. }\end{array}$ \\
\hline
\end{tabular}

Source: Compiled by the authors. 
The proposed sEm model specification in this study consists of one endogenous variable, not directly measurable or latent, and two unobserved independent variables:

$\eta=y_{1} \xi_{1}+y_{2} \xi_{2}+\zeta$

where $\eta$ is the latent endogenous variable - port authority's values and their transmission-; $\xi$ is the independent variable, not directly measurable - relational climate between stakeholders and the port authority-, and $\xi_{2}$ is the second independent variable, not directly measurable - port environmental conditions-. Finally, $\zeta$ represents the observed perturbation, besides the randomisation of the model, the possible effects of omitted variables and errors of measurement.

The measurement equations for the endogenous latent variable are as follows:

$$
\begin{aligned}
& Y_{1}=X_{1} \eta+\varepsilon_{1} \\
& Y_{2}=X_{2} \eta+\varepsilon_{2}
\end{aligned}
$$

where measurements for the variables are: Y1: the port authority participates in social affairs; Y2: the port authority encourages stakeholders to participate in its social values.

The measurement equations for the relational climate with the stakeholder variable are as follows:

$$
\begin{aligned}
& X_{1}=\lambda^{x}{ }_{11} \xi_{1}+\delta_{1} \\
& X_{2}=\lambda^{x}{ }_{21} \xi_{1}+\delta_{2} \\
& X_{3}=\lambda^{x}{ }_{31} \xi_{1}+\delta_{3} \\
& X_{4}=\lambda^{x}{ }_{41} \xi_{1}+\delta_{4}
\end{aligned}
$$

The measurement equations for the environmental conditions variable are as follows:

$$
\begin{aligned}
& X_{5}=\lambda^{x}{ }_{52} \xi_{2}+\delta_{5} \\
& X_{6}=\lambda^{x}{ }_{62} \xi_{2}+\delta_{6} \\
& X_{7}=\lambda^{x}{ }_{72} \xi_{2}+\delta_{7}
\end{aligned}
$$

\section{The Model Hypothesis}

The initial hypothesis was proposed with the aim of ascertaining whether the application of the Ports Act of $2010(33 / 2010)$ and the role of port authorities is becoming more perceptible and that entrepreneurs and organizations within the port are exchanging enough information concerning the port authority's values.

Hypothesis 1 . There is a direct effect $(\gamma 1)$ with regards to the relational climate between the port authority and the stakeholders and the port authority's transmission of values (Yongrok \& Yu, 2014). Vinerean et al. (2013) propose the same hypothesis; however, on referring to the working environment, they regard employees as stakeholders. Generally speaking, the environmental effect resulting from this would be expected to be positive and important.

Hypothesis 2. The effort and course of action concerning environmental conditions $\left(\gamma_{2}\right)$ have a direct impact on the perceptions with regards to the port authority's values and their transmission. The resources which are intended for the benefit and protection of the environment will be relayed to the stakeholders, any course of action in this field would suggest showing empathy towards nature itself, a compromise with future generations, and so on. As a result, a positive effect stemming from the perceptions held by the stakeholders concerning any environmental action taken by the port authority would be expected.

Hypothesis 3. There are indirect effects on the independent variable. These effects occur when the impact of an explanatory variable is channelled indirectly towards the endogenous variable via the remaining explanatory variables. The intensity of the said indirect effect is measured by means of the product of the respective direct effects.

The series of relations between the variables in the model, together with the causal effects are represented in figure 1 . The arrows show the direction of the effects among the variables. The designation of each of the observable variables are to be found in tables 1 and 2 . 


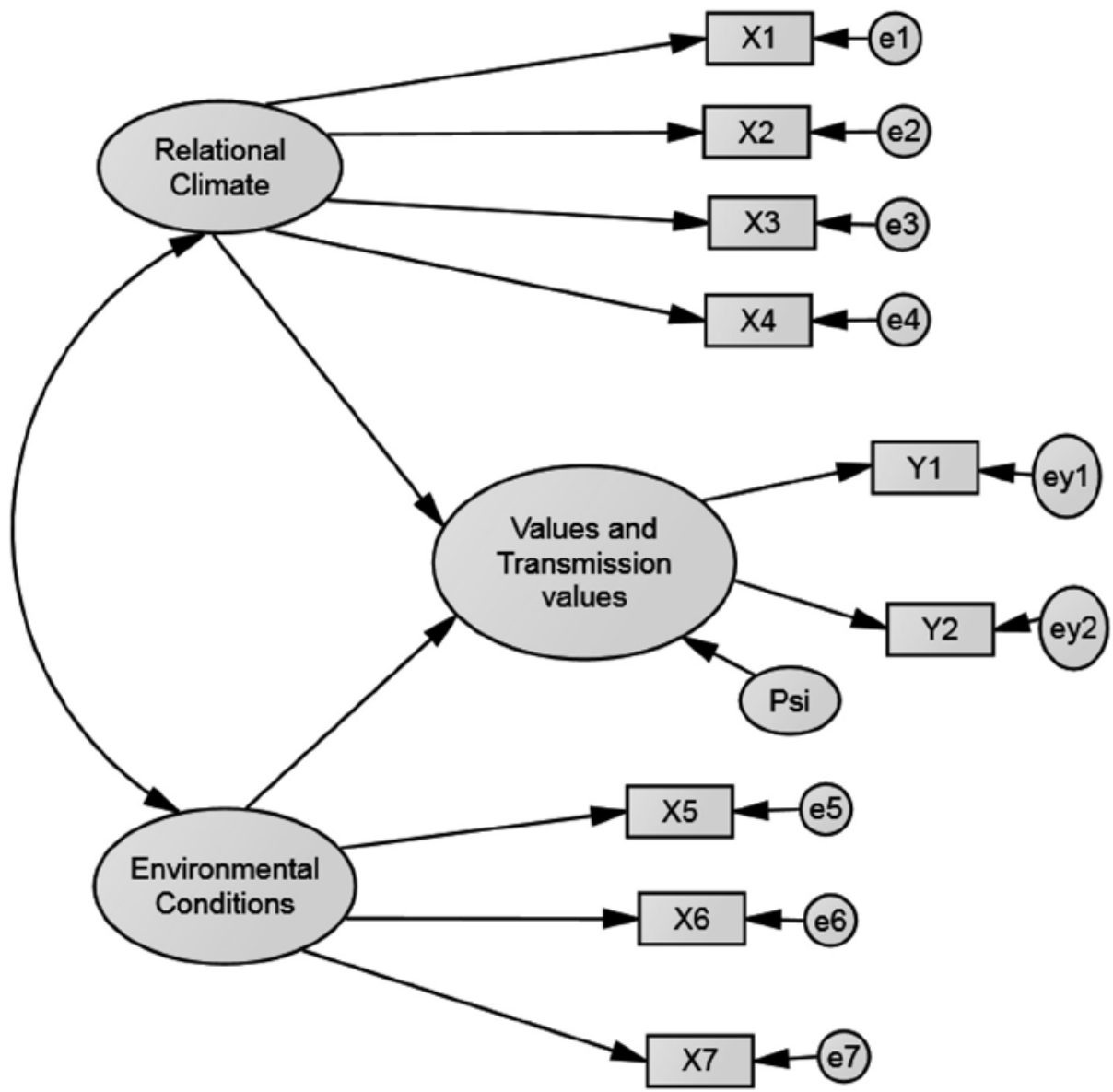

Figure 1. SEM model specification. Source: Compiled by the authors.

\section{Estimation of Structural Equation Model (SEM)}

\section{Sample design}

The population sample frame for this study is made up of 68 companies and organizations who carry out business transactions within the port area, 12 of which are state owned and the remaining 56 are privately run. For the sampling procedure a stratified randomization sample was used due to the private/public nature of the businesses. The sample frame is made up of 39 companies and 9 state-run organizations. ${ }^{2}$ The method for data collection was by means of personal interviews carried out in the middle of 2011. The variables are measured according to the Likert scale from 1 (totally disagree) to 5 (totally agree.)

2. The estimates of sampling error are presented in Annex I

\section{Method of estimation}

The research work cited in the literature review, which applies SEM models in order to study the perceptions by using the Likert scale (Hongwei \& Yan, 2011; Yongrok \& Yu, 2014), recommend that, to obtain consistent and efficient estimates, the variables must comply with certain conditions, such as reliability and measurement scale consistency concerning multivariate normality.

To be able to evaluate reliability and measurement scale consistency, Cronbach's Alpha statistic is applied. The results for not only internal consistency for each latent variable, but also for the general model are presented in table 3. According to Oviedo and Campo (2005), the expected maximum value is 0.9 , any value above this is considered redundant and redundant items should therefore be eradicated. Usually, alpha statistic values are preferred to lie within 0.8 and 0.9 ; however, in practice, values which are slightly lower than this are acceptable. 
Table 3

Statistics for Measurement Scale Reliability

\begin{tabular}{cccc}
\hline Hidden variables & Cronbach's Alpha & $\begin{array}{c}\text { Cronbach's Alpha based on typified } \\
\text { elements }\end{array}$ & Number of elements \\
\hline Relational climate & 0.838 & 0.842 & 4 \\
\hline Environment & 0.828 & 0.831 & 3 \\
\hline Transmission of values and CSR & 0.806 & 0.815 & 2 \\
\hline Total & 0.744 & & 9 \\
\hline
\end{tabular}

Source: Compiled by the authors.

In table 3, Cronbach's Alpha reaches values between 0.838 and 0.806 for the different latent variables, and 0.744 in total, these values for scale reliability and consistency therefore being acceptable.

West et al. (1995) assure that there should be no need for concern in the case of abnormality if the variable bias does not exceed 2, while kurtosis does not exceed 7. The values of bias and kurtosis are presented in table 4 for the set of variables which coincide with the criteria stated by West et al. (1995), the possible effects of abnormality are not important.

Table 4

Estimates of Normality

\begin{tabular}{lrr}
\hline \multicolumn{1}{c}{ Variables } & Bias & Kurtosis \\
\hline $\mathrm{Y}_{1}$ : the port authority participates actively in areas of social interest. & -0.404 & -1.094 \\
\hline $\mathrm{Y}_{2}$ : the port authority ensures stakeholders partake in their values. & -0.378 & -0.206 \\
\hline $\mathrm{X}_{1}$ : businesses feel fully integrated in the port. & -0.125 & -0.737 \\
\hline $\mathrm{X}_{2}$ : the port authority takes measures to improve relations with stakeholders. & -0.145 & -0.355 \\
\hline $\mathrm{X}_{3}$ : services provided by the port authority offer clear, transparent information. & -0.309 & 0.433 \\
\hline $\mathrm{X}_{4}:$ the port authority pays heed to any suggestions put forward by customers and & -0.186 & -0.805 \\
entrepreneurs within the port area. & -0.062 \\
\hline $\mathrm{X}_{5}$ : the port authority gives sufficient importance to environmental pollution. & -0.067 \\
\hline $\mathrm{X}_{6}$ : the port authority gives sufficient importance to land pollution. & -0.294 & -0.282 \\
\hline $\mathrm{X}_{7}$ : the port authority gives sufficient importance to noise pollution. & -1.97 \\
\hline
\end{tabular}

Source: Compiled by the authors.

Wang et al. (1996) claim that, when the sample is not very extensive and due to the sensibility of maximum likelihood with regards to abnormality, a series of alternative techniques for estimation have been developed. However, if the variables are not too distant from being normal, it is preferable to use the maximum likelihood estimation method with small-sized samples, as is the case of this research work.

The estimation has been carried out by means of the Maximum Likelihood Estimation approach. The logarithm for the likelihood function is as follows:

$$
\log L=-\frac{1}{2}(n-1)\left\{\log |\Sigma(\theta)|+\operatorname{tr}\left|\mathbf{s} \Sigma(\theta)^{-1}\right|\right\}+k
$$

where $S$ is the matrix of covariant or observed sampling while $\Sigma(\theta)$ is the matrix of the covariant theories of the model; $\mathrm{n}$ represents the sample size and $\mathrm{K}$ is a constant variable. Maximising the function of likelihood (4) is equivalent to minimising the differences between the two matrixes: observed (S) and theoretical $\Sigma(\theta)$ : 


$$
M L E=\log |\Sigma(\theta)|-\log |\mathrm{S}|+|t r| \mathrm{s} \Sigma(\theta)^{-1} \mid-p
$$

where MLE represents the value of the likelihood function and $\mathrm{p}$ is the number of observable variables.

In SEM models, the foremost general procedure to find out whether the model is identifiable or not is by way of the concept of degrees of freedom (d.f.): $d f=1 / 2$ [ $(p+q)(p+q+1)]-t>0 . p$ is the number of endogenous indicators ( 3 in the proposed model); $q$ is the number of exogenous indicators ( 7 in the model), and $t$ is the number of estimated coefficients ( 23 in the proposed model). Accordingly, after substituting the indicators for the following values, the resulting equation is as follows: $d f=$ $1 / 2[(2+7)(3+7+1)]-23=12$. The model has therefore been specified, complying with the condition " $d f>0$ ".

\section{Results, Contrasts and Interpretations}

The estimated model for the maximum likelihood approach is as follows:

$$
\hat{\eta}=0.48 \xi_{1}+(-0.32) \xi_{2}
$$

The first explanatory variable $\xi_{1}$ (relational climate) produces a direct effect ( 0.48$)$ on the dependent variable $\eta$-values and transmission of port authority CSR values-. The second explanatory variable $\xi_{2}$ (environment) has a negative impact on the dependent variable $\eta$. All the results of the estimations are set out in figure 2 .

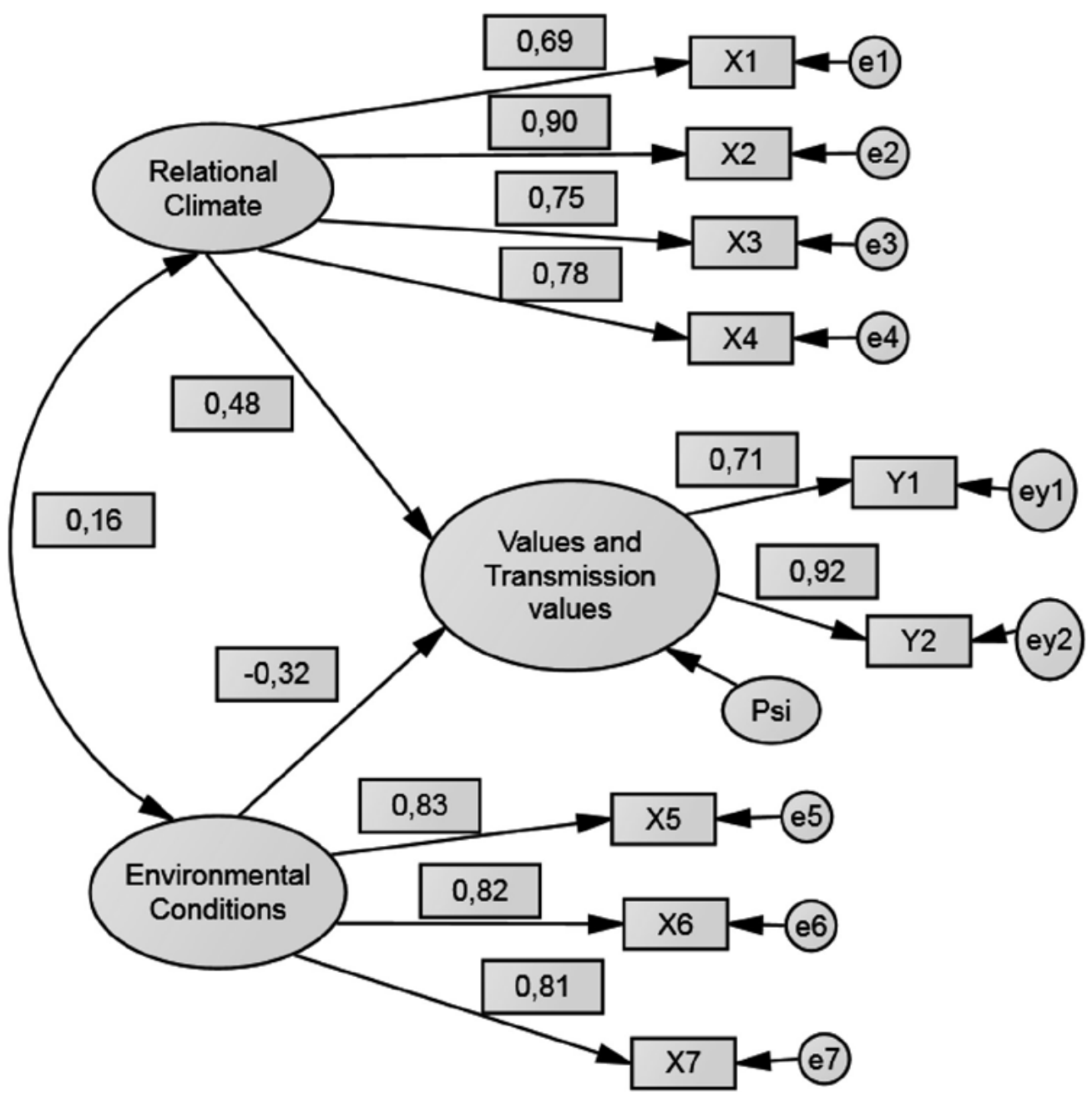

Figure 2. Sem model estimation. Source: Compiled by the authors. 
The values appearing alongside the arrows show the intensity (correlation) between the variables and are taken to mean their corresponding effects. The direct effect which arises as a result between the two exogenous latent variables is significant, but only reveals a low level of intensity (0.16.) The remaining values in the diagram are summarised in table 5 , as follows.

Table 5

Estimations and Individual Contrasts

\begin{tabular}{|c|c|c|c|}
\hline Variables & Estimations $^{\mathrm{a}}$ & C.R. & $\mathbf{P}^{\mathrm{b}}$ \\
\hline $\mathrm{Y}_{1}$ : the port authority participates actively in areas of social interest. & 0.71 & 14.029 & $* * *$ \\
\hline $\mathrm{Y}_{2}$ : the port authority ensures stakeholders partake in their values. & 0.92 & 25.817 & $* * *$ \\
\hline $\mathrm{X}_{1}$ : businesses feel fully integrated in the port. & 0.69 & 23.139 & $* * *$ \\
\hline $\mathrm{X}_{2}$ : the port authority takes measures to improve relations with stakeholders. & 0.90 & 21.565 & $* * *$ \\
\hline $\mathrm{X}_{3}$ : services provided by the port authority offer clear, transparent information. & 0.75 & 20.341 & $* * *$ \\
\hline $\begin{array}{l}\mathrm{X}_{4} \text { : the port authority pays heed to any suggestions put forward by customers and } \\
\text { entrepreneurs within the port area. }\end{array}$ & 0.78 & 10.417 & $* * *$ \\
\hline $\mathrm{X}_{5}$ : the port authority gives sufficient importance to environmental pollution. & 0.83 & 18.46 & $* * *$ \\
\hline $\mathrm{X}_{6}$ : the port authority gives sufficient importance to land pollution. & 0.82 & 15.264 & $* * *$ \\
\hline $\mathrm{X}_{7}$ : the port authority gives sufficient importance to noise pollution. & 0.81 & 19.418 & $* * *$ \\
\hline
\end{tabular}

Note. ${ }^{\text {a }}$ Standard factorial design estimations; ${ }^{\text {b }}$ Significance deviation with $\alpha \leq 0.05$. Source: Compiled by the authors.

CR values are used for individual significance contrasts; in practice, values greater than 2 indicate that the estimations are statistically significant.

As an initial step to model adjustment, the covariant matrixes - both observed and theoretical - are contrasted to corroborate whether they are independent or not. To do so, the following statistical estimations are used: $\chi^{2} / \mathrm{df}=28.748 / 6=1.1$; as the statistical cut-off value is 5 , and the statistical value observed is 1.1, the independent statistical hypothesis has been rejected, and initially speaking, the specified theoretical model acceptably represents the observed covariant matrix.

The remaining contrasts set out in the Index of Good Fit Adjustments Table (Table 6) is additional corroboration of goodness of fit provided by the software package Amos. The Normed Fit Index (NFI) is an index whose values fall within the interval of [0.1], values close to whole numbers, thereby showing goodness of fit between both matrixes (observed and estimated). The Comparative Fit Index (CFI) values which show to be higher than 0.95 also add to the fact that goodness of fit exists. The Root Mean Square Error of Approximation (RMSEA), values of approximately 0.05 , is a sign of goodness of fit, but models with values higher than 0.10 should not be considered as acceptable. In table 4 , a summary of the results is presented which corresponds to the above-mentioned statistics for goodness of fit. All the estimates present values within acceptable ranges, indicating goodness of fit between observable and theoretical models.

Table 6

Adjustment of Goodness of Fit Index

$$
\begin{aligned}
\chi^{2}=28.748 ; \mathrm{df} & =26 ; \chi^{2} / \mathrm{df}=1.1, \text { cut-off value: } \chi^{2} / \mathrm{df}<5 ; \\
\text { NFI } & =0.9, \text { cut off value: } \mathrm{NFI} \geq 0.9 ; \\
\text { CFI } & =0.98, \text { cut off values: } 0.90 \leq \text { CFI } \leq 1 ; \\
\text { RMSEA } & =0.047, \text { cut off value: } \text { RMSEA }<0.05
\end{aligned}
$$

Source: Compiled by the authors.

In obtaining the aforementioned results, together with the formulated hypotheses, the following interpretations have been derived:

Hypothesis 1. A direct and positive effect was observed between the relational climate and port authority ethical values (0.48). In other words, hypothesis 1 is acceptable: the efforts made to improve relations with stakeholders also improve the perceptions held by the former regarding port authority values. Moreover, the results obtained recommend that not only should collaboration between both parties be boosted and heed be paid to stakeholders' proposals, but also allow for reciprocal decision-making, as well as avoiding any discriminatory situations. According 
to the model, these are actions which will strengthen and propagate CSR values from port authorities to other organisations and businesses throughout the port area: a positive environment leads to positive outcomes within the organisation (Vinerean et al., 2013).

Hypothesis 2. The environment variable is seen to have a direct effect on the endogenous port authority values variable. Nevertheless, the value of the estimated effect produced an unexpected negative value $(-0.32)$. There is a wide range of possible interpretations for this negative value; the causes could be found in problems concerning communication, participation, unsatisfactory measures dealing with land, coastal, noise and atmospheric contamination, all of which generate negative perceptions from the stakeholders' point of view. According to Chieh-Peng Lin et al. (2010), at times CSR may have a negative impact on organisations; even though efforts are made to counteract this situation, they are not effectual - discretionary measures-.

Hypothesis 3. The causal variables - relational climate and environment - have indirect effects on the dependent variable - port authority values-, but are not representative. The first, the indirect effect of relational climate owing to the environment is obtained by means of the product of their effects: $\rho\left(\xi_{1} \xi_{2}\right) \rho\left(\eta \xi_{1}\right)=0.16(-0.32)=-0.05$. The second, the indirect effect of the environment on the dependent variable owing to the relational climate variable is only very slight: $\rho\left(\xi_{1} \xi_{2}\right) \rho\left(\eta \xi_{2}\right)=0.16(0.48)=0.077$. Both effects are statistically significant; however, the estimated values are very low, so the impact they have is almost void.

\section{Conclusions}

Following the implementation of the Spanish Ports Act of 2010 (33/2010), the submission of an annual Sustainability Report is compulsory. In spite of being an ideal channel of communication with groups that support CSR, the reports are still a source of weakness in that they neither clarify agreements, nor measures which have been set out, nor the deadlines for settling undesirable circumstances. Barring the fact that reports become far too technical, as they are based on an excessive number of indicators, they also squander resources; without moving on from this stage, port authorities run the risk of becoming unstuck in the Systematic Filling out of Forms syndrome. To determine the most effective measures with a view to
CSR planning, perception surveys are a complementary approach to backing up the reports.

CSR is playing an ever-growing role in the day-today running of port authorities; each port authority has its own traits, and thereby conducts measures which it considers the most beneficial for all port benefactors.

The research results recommend that the most effective CSR actions within the port to foster the relational climate are to be attentive, promote integration, inform and encourage business entrepreneurs to participate in common affairs of interest. At the same time, the port authority should pay more attention to activities concerning the environment, that is to say, pollution of all kinds - coastal, land and air contamination, amongst others- since entrepreneurs are fully aware of the fact that efforts in this field may be at times insufficient or unsatisfactory. Subsequently, with regards to the research work carried out on this port, the environmental aspects are hindering the divulgation of port authority's values and CSR measures.

This research work has been carried out on only one Spanish port, considered one of the most important in the country and, due to its geostrategic position, sits in the midst of international maritime traffic. With regards to any further research in the future, the sampling could be widened to include other ports. However, it is possible that the variables which go towards making up each of the dimensions in each port will suffer slight variations, since the stakeholders' perceptions as well as CSR measures are influenced by cultural, economic, geographical and social factors, according to the explanations given by Eun Mi Lee et al. (2013), and Aguinis and Glavas (2012).

\section{References}

Aguinis, H., \& Glavas, A. (2012). What we know and don't know about corporate social responsibility: A review and research agenda. Journal of Management, 38(4), 932-968. https://doi.org/10.1177/0149206311436079

Alvarado, A., \& Schlesinger, M. W. (2008), Dimensionalidad de la responsabilidad social empresarial percibida y sus efectos sobre la imagen y la reputación: una aproximación desde el modelo de Carroll. Estudios Gerenciales, 24(108), 37-59. https://doi.org/10.1016/ S0123-5923(08)70043-3

Boza, J. (2011). La responsabilidad social de las empresas y la cultura de la certificación. Atlantic Economic Review, 1, 1-20. 
Caro, F., García Gordillo, M., Rodríguez, C., \& Jiménez, G. (2007). Techo de cristal en las empresas periodísticas: percepción de las habilidades y capacidades de la mujer en las tareas de dirección. Ámbitos, 16, 395-407.

Carroll, A. B. (1991). The pyramid of corporate social responsibility: Toward the moral management of organizational stakeholders. Business Horizons, 34(4), 39-48. https://doi.org/10.1016/0007-6813(91)90005-G

Chernyak-Hai, L., \& Tziner, A. (2014). Relaciones entre comportamiento laboral contraproducente, justicia percibida y clima, estatus ocupacional e intercambio líder-subordinado. Journal of Work and Organizacional Psychology, 30(1), 1-12.

Chieh-Peng, L., Nyan-Myau, L., Yuan-Hui, T., Wen-Yung, C., \& Chou-Kang, Ch. (2010). Modeling corporate citizenship and its relationship with organizational citizenship behaviors. Journal of Business Ethics, 95, 357-372. https://doi.org/10.1007/s10551-010-0364-X

Eun Mi, L., Seong-Yeon, P., \& Hyun Jung, L. (2013). Employee perception of csR activities: Its antecedents and consequences. Journal of Business Research, 66, 1716-1724. https://doi.org/10.1016/j.jbusres.2012.11.008

Fassin, Y., Werner, A., Van Rossem, A., Signori, S., Garriga, E., von Weltzien Hoivik, H., \& Schlierer, H. J. (2014). CSR and related terms in SME owner-managers' mental models in six European countries: National context matters. Journal of Business Ethics, 128(2), 1-24.

Hamman, E. M., Habisch, A., \& Pechlaner, H. (2009). Values that create value: Socially responsible business practices in SMES-empirical evidence from German companies. Business Ethics: A European Review, 18(1), 37-51. https://doi.org/10.1111/j.1467-8608.2009.01547.x

Herrera, J., Larrán, J. M., \& Martínez, D. (2013). Relación entre la Responsabilidad Social y performance en las pequeñas y medianas empresas: revisión bibliográfica. Cuadernos de Gestión, 13(2), 39-65. https://doi. org/10.5295/cdg.120360jh
Hongwei, H., \& Yan, L. (2011). CSR and service brand: The mediating effect of brand identification and moderating effect of service quality. Journal of Business Ethics, 100(4), 673-688. https://doi.org/10.1007/s10551-010-0703-y

Johnson, G. \& Scholes, K. (1999). Exploring corporate strategy. Harlow: Prentice Hall, 5th Edition.

Leipziger, D. (2003). The corporate responsibility code book. London: Greenleaf Publishing.

Oviedo, H., \& Campo, A. (2005). Aproximación al uso del coeficiente alfa de Cronbach. Revista Colombiana de Psiquiatría, XXXIV(4), 570-580.

Steurer, R. (2010). The role of governments in corporate social responsibility: Characterising public policies on CSR in Europe. Policy Sciences, 43(1), 49-72. https:// doi.org/10.1007/s11077-009-9084-4

Vinerean, S., Cetină, I., Dumitrescu, L., \& Țichindelean, I. (2013). Modelling employee engagement in relation to CSR practices and employee satisfaction. Revista Económica, 65(1), 21-37.

Wang, L., Fan, X., \& Wilson, V. (1996). Effects of nonnormal data on parameter estimates and fit indices for a model with latent and manifest variables: An empirical study. Structural Equation Modeling: A Multidisciplinary Journal, 3(3), 228-247. https://doi. org/10.1080/10705519609540042

West, S. G., Finch, J. F., \& Curran, P. J. (1995). Structural equation models with nonnormal variables: Problems and remedies. In R. H. Hoyle (Ed,), Structural equation modeling: Concepts, issues, and applications (pp. 56-75). Thousand Oaks, CA: Sage Publications.

Wood, D. J. (1991). Corporate social performance revised. Academy of Management Review, 16(4), 691-718. https://doi.org/10.2307/258977, https://doi.org/10.5465/ AMR.1991.4279616

Yongrok, Ch., \& Yu, Y. (2014). The influence of perceived corporate sustainability practices on employees and organizational performance. Sustainability, 6, 348364. https://doi.org/10.3390/su6010348 


\section{Annex I. Sampling errors}

Stratified sampling with two strata has been used. The first stratum encompasses public organisms and organisations which play an active role within the port. The second stratum includes firms and companies which operate in the port area. For each one of the variables, the respective sampling errors have been estimated. On the whole, the estimated sampling errors are considered acceptable with a confidence level of $95 \%$, with almost all variables standing in or around 5\%, the exception being that of the sampling error of the $\mathrm{X}_{6}$ variable, which stands at $6.5 \%$.

$$
\bar{x}_{s t}=\sum_{h=1}^{3} W_{h} \bar{x}_{h} \quad v\left(\bar{x}_{s t}\right)=v\left(\sum_{h=1}^{L} w_{h} \bar{x}_{h}\right)=\sum_{h=1}^{L} w_{h}^{2} v\left(\bar{x}_{h}\right) \quad \mathrm{E}=\mathrm{z}_{\alpha / 2} \sqrt{\operatorname{Var}(\bar{x})}
$$

Table IA

Estimations of Sampling Errors

\begin{tabular}{|c|c|c|c|c|c|c|c|c|c|}
\hline $\mathrm{N}=$ & 68 & $\mathrm{~N}_{1}=$ & 12 & $\mathrm{~N}_{2}=$ & \multicolumn{5}{|l|}{56} \\
\hline $\mathrm{n}=$ & 48 & $\mathrm{n}_{1}=$ & 9 & $\mathrm{n}_{2}=$ & \multicolumn{5}{|l|}{39} \\
\hline$(\mathrm{N}-\mathrm{n}) / \mathrm{N}=$ & 0.294 & & & & & & & & \\
\hline \multicolumn{10}{|c|}{ Estimations } \\
\hline Stratum I & $\mathrm{X}_{1}$ & $\mathrm{X}_{2}$ & $\mathrm{X}_{3}$ & $\mathrm{X}_{4}$ & $\mathrm{X}_{5}$ & $\mathrm{X}_{6}$ & $\mathrm{X}_{7}$ & $\mathrm{Y}_{1}$ & $\mathrm{Y}_{2}$ \\
\hline Medias $=$ & 4.000 & 3.042 & 3.146 & 3.354 & 3.229 & 2.917 & 2.792 & 2.271 & 2.810 \\
\hline $\mathrm{S}_{1}{ }^{2}=$ & 0.571 & 0.214 & 0.839 & 0.268 & 0.411 & 1.268 & 0.411 & 0.268 & 0.571 \\
\hline $\mathrm{S}_{1}^{2} / \mathrm{n}_{1}=$ & 0.063 & 0.024 & 0.093 & 0.030 & 0.046 & 0.141 & 0.046 & 0.030 & 0.063 \\
\hline Stratum II & $\mathrm{X}_{1}$ & $\mathrm{X}_{2}$ & $\mathrm{X}_{3}$ & $\mathrm{X}_{4}$ & $\mathrm{X}_{5}$ & $\mathrm{X}_{6}$ & $\mathrm{X}_{7}$ & $\mathrm{Y}_{1}$ & $\mathrm{Y}_{2}$ \\
\hline Medias $=$ & 3.225 & 2.900 & 3.050 & 3.350 & 3.300 & 2.875 & 2.775 & 2.200 & 2.750 \\
\hline $\mathrm{S}_{2}{ }^{2}=$ & 0.553 & 0.913 & 1.228 & 1.362 & 1.292 & 1.548 & 0.897 & 0.677 & 0.654 \\
\hline $\mathrm{S}_{2}^{2} / \mathrm{n}_{2}=$ & 0.014 & 0.023 & 0.031 & 0.035 & 0.033 & 0.040 & 0.023 & 0.017 & 0.017 \\
\hline \multicolumn{10}{|c|}{ Global averages } \\
\hline$\underline{X}_{s t}=$ & 3.362 & 2.925 & 3.067 & 3.351 & 3.288 & 2.882 & 2.778 & 2.213 & 2.761 \\
\hline $\mathrm{V}\left(\underline{\mathrm{X}}_{\mathrm{st}}\right)=$ & 0.003 & 0.005 & 0.007 & 0.007 & 0.007 & 0.009 & 0.005 & 0.004 & 0.004 \\
\hline$E=$ & 0.11 & 0.14 & 0.17 & 0.17 & 0.17 & 0.19 & 0.14 & 0.12 & 0.12 \\
\hline $\mathrm{E}(\%)=$ & $3.4 \%$ & $4.7 \%$ & $5.4 \%$ & $5.0 \%$ & $5.1 \%$ & $6.5 \%$ & $5.0 \%$ & $5.5 \%$ & $4.5 \%$ \\
\hline
\end{tabular}

Source: Compiled by the authors. 